Neurosurg Focus 5 (4):Article 7, 1998

\title{
Early and aggressive treatment of medically intractable cerebral vasospasm with pentobarbital coma, cerebral angioplasty and ICP reduction
}

\author{
Rocco A. Armonda M.D., Jeffrey E. Thomas, M.D., and Robert H. Rosenwasser, M.D. \\ Division of Cerebrovascular Surgery and Interventional Neuroradiology, Department of Neurosurgery, Thomas Jefferson University, \\ Philadelphia, Pennsylvania
}

The authors present the unique experience of one neurovascular service under the direct supervision of the senior author, for which surgical, endovascular, and intensive care treatments were conducted in a select group of 32 patients with aneurysmal subarachnoid hemorrhage who had medically intractable symptomatic vasospasm.

A protocol of early and aggressive treatment was instituted using pentobarbital coma, cerebral angioplasty, and intracranial pressure (ICP) reduction. The patient population consisted of 25 women and seven men, whose ages ranged from 34 to 60 years (average 47 years). The patients' Hunt and Hess grades on presentation were as follows: Grade 0 (one); Grade I (three); Grade II (two); Grade III (nine); Grade IV (10); Grade V (seven). Microsurgical clipping alone was performed in 15 of 32 patients, endosaccular occlusion was performed in 17 of 20 patients, and two patients underwent combined treatment. Subsequent angioplasty was performed in 26 of 32 patients. Additionally, all 32 patients underwent treatment of increased ICP with ventriculostomy placement, removal of the bone flap (11), evacuation of associated intracranial hematoma (five), and decompressive obectomy (four).

Twenty-one patients survived and 11 died. Of the 21 survivors, seven have returned to work, live independently, and have no neurological deficits; eight require minimal assistance at home; four are in rehabilitation with moderate deficits at 3 months; and two remain in a persistent vegetative state.

In this group of aggressively treated patients who received pentobarbital cerebral protection, successful treatment of medically intractable cerebral vasospasm was related to time of treatment ( $<2$ hours), expeditious reduction of elevated ICP, and angioplasty.

Key Words * vasospasm * barbiturate therapy * angioplasty

Vasospasm caused by aneurysmal subarachnoid hemorrhage (SAH) remains a source of considerable morbidity and mortality that adversely affects between 10 and $20 \%$ of patients. The purpose of our study is to review the effects of using pentobarbital-induced coma on outcome in patients with medically intractable vasospasm.

\section{CLINICAL MATERIAL AND METHODS}

We report our experience in 32 patients with aneurysmal SAH who had medically intractable symptomatic vasospasm (Table 1). 


\begin{tabular}{|c|c|c|c|c|c|c|c|c|}
\hline $\begin{array}{l}\text { Case } \\
\text { No. }\end{array}$ & $\begin{array}{l}\text { Age } \\
\text { (yrs] }\end{array}$ & Grade & $\begin{array}{l}\text { Aneurysm } \\
\text { Location }\end{array}$ & $\begin{array}{l}\text { Areurysm } \\
\text { Treatmerk }\end{array}$ & $\begin{array}{l}\text { DeficitsiTCD } \\
\text { Measuremerts }\end{array}$ & $\begin{array}{l}\text { Arngio plastyl } \\
\text { Pent obar bital }\end{array}$ & $\begin{array}{l}\text { Associated } \\
\text { Illnesses }\end{array}$ & Outcome \\
\hline 1 & 39 & GO & tilat MCA & $\begin{array}{l}\text { FT draniot, It } \\
\text { MCA clipping }\end{array}$ & $\begin{array}{l}\text { receptive aphasia; } \\
\text { rt hemi paresis }\end{array}$ & $\begin{array}{l}\text { POD } 1 \mathrm{HHH} \text {; POD } 6 \text { EDH } \\
\text { evaduated, bone plate re- } \\
\text { mowed angioplasty } \times 3-1 \\
\text { tranch ocdusion; } \mathrm{PB} \text { begun } \\
\text { at } 2^{\circ}\end{array}$ & $\begin{array}{l}\text { pneum onia, sepsis, } \\
\text { septic arthritis, ALI, } \\
\text { MOD }\end{array}$ & $\begin{array}{l}\text { independent, mild } \\
\text { rt paresis; walks } \\
\text { wo help }\end{array}$ \\
\hline 2 & 55 & F3RIII & $\begin{array}{l}\text { It POOA rup- } \\
\text { tured ACOA }\end{array}$ & $\begin{array}{l}\text { rt FT craniot, } \\
\text { clipping, Iv' }\end{array}$ & $\begin{array}{l}\text { increased ICP, } \mathrm{PH} 4 \\
\text { It hemi paresis; } \mathrm{HHH} \\
\text { TCD = 132-211, } \\
\text { rt MCA }\end{array}$ & $\begin{array}{l}\mathrm{POD} 3: \mathrm{PB}>2^{\circ} \text {, angioplasty, } \\
\text { GDC of It } \mathrm{PO} \mathrm{A}^{\prime} ; \text { bone plate } \\
\text { remowed }\end{array}$ & parotitis & $\begin{array}{l}\text { li ies at home; par- } \\
\text { tiallyde pendent } \\
\text { for ADL }\end{array}$ \\
\hline 3 & 43 & F3Gill & ACOA & $\begin{array}{l}\text { rt FT craniot } \\
\text { ACoA clipping } \\
\text { IVC }\end{array}$ & POD 10 It hemiplegia & $\begin{array}{l}\text { POD } 11 \text { angioplasty; } P O D 12 \\
\text { IVC; } P O D 12 \text { PB after ICP in- } \\
\text { crease }>20\end{array}$ & pneum onia & $\begin{array}{l}\text { independent, w/ } \\
\text { mild It hemipare- } \\
\text { sis }\end{array}$ \\
\hline 4 & 44 & F3KIII & It $P C O A$ & $\mathrm{GDC}$ & $\begin{array}{l}\text { POD } 4 \text { UE drift; } \mathrm{HHH}_{\mathrm{i}} \\
\text { POD } 5 \text { tem poral lobe/ } \\
\text { pedunde hem }\end{array}$ & $\begin{array}{l}\text { POD } 6 \text { PB }\left(6^{\circ}\right) \text {, unresponsive } \\
\text { to IVC; } \mathrm{POD} 7 \text { tilat } M_{1} \text { angio- } \\
\text { plasty }\end{array}$ & $\begin{array}{l}\text { pneum onia, sepsis } \\
\text { ALI, MOD }\end{array}$ & $\begin{array}{l}\text { li ies at home; de- } \\
\text { pendent for } \mathrm{ADL}\end{array}$ \\
\hline 5 & 47 & $\mathrm{~F} 3 \mathrm{Gl}$ & $\begin{array}{l}\text { MCA, } r t \\
\text { ACOA }\end{array}$ & $\begin{array}{l}\text { rt craniot, dip- } \\
\text { ping }\end{array}$ & $\begin{array}{l}\text { POD } 4 \text { hemi pare sis, re- } \\
\text { sponded to } \mathrm{HHH} \text {, then } \\
\text { increased }\end{array}$ & $\begin{array}{l}\mathrm{POD} 4 \text { angio plasty, } \mathrm{POD} 8 \mathrm{~PB} \\
\text { w/ele vated } \mathrm{TCD} \text {; bone plate } \\
\text { removed }\end{array}$ & ALI & $\begin{array}{l}\text { independent; re- } \\
\text { turned to work }\end{array}$ \\
\hline 6 & 49 & F3GIII & ACOA & $\begin{array}{l}\text { rt FT craniot, } \\
\text { clipping }\end{array}$ & $\begin{array}{l}\text { sinollen train, intraop } \\
\text { PB }\end{array}$ & $\begin{array}{l}\text { immediate PB }\left(<1^{*}\right) \text {; bone plate } \\
\text { kept off }\end{array}$ & $\begin{array}{l}\text { pneum onia, ARDS; } \\
\text { Sepsis, w/ALLI } \\
\text { MOD }\end{array}$ & $\begin{array}{l}\text { independent, mild } \\
\text { memory dystunc- } \\
\text { tion; returned to } \\
\text { work }\end{array}$ \\
\hline 7 & 60 & GIV & PICA & GDC & IVC-VP shunt & PB (1\%); angioplasty & $\begin{array}{l}\text { pneum onia, ARDS; } \\
\text { MOD }\end{array}$ & $\begin{array}{l}\text { independent, re- } \\
\text { turned to normal } \\
\text { function }\end{array}$ \\
\hline 8 & 45 & F3Rill & PICA & GDC & $\begin{array}{l}\text { IVC post-GDC; sei- } \\
\text { zure IVC X } 3\end{array}$ & $\begin{array}{l}\text { PHD } 2 \text { PB (19); intractable ICP } \\
\text { vasospasm; diffuse small- } \\
\text { wessel spasm }\end{array}$ & hypertension & died \\
\hline 9 & 55 & F3GIII & It $\mathrm{PCOA}$ & $\begin{array}{l}\text { IVC PHD } 2 \\
\text { It FT craniot } \\
\text { PHD } 3\end{array}$ & $\begin{array}{l}\text { POD } 7 \text { rapid o btunda- } \\
\text { tion, IVC for increased } \\
\text { IOP; PHD } 10 \text { IVC X2 }\end{array}$ & distal spasm, poor com pliance & $\begin{array}{l}\text { pneum onia, ALI } \\
\text { MOD }\end{array}$ & died \\
\hline 10 & 38 & $\mathrm{~F} 3 \mathrm{GlV}$ & ACOA & $\begin{array}{l}\text { rt FT craniot, } \\
\text { in traop rupture; } \\
\text { GDC of residual } \\
\text { aneurysm }\end{array}$ & PHD 5 elevated TCDs & angioplasty of it $M_{1}$ carotid & $\begin{array}{l}\text { pneum onia, } \\
\text { tracheitis ALLI }\end{array}$ & $\begin{array}{l}\text { independent, re- } \\
\text { turned to work }\end{array}$ \\
\hline 11 & 34 & $\mathrm{~F} 3 \mathrm{GN}$ & BA & IVC, GDC & PHD 7 increased ICP & $\begin{array}{l}\text { PB; tifrontal craniot; angio- } \\
\text { plasty }\end{array}$ & $\begin{array}{l}\text { pneum onia, line } \\
\text { infection }\end{array}$ & $\begin{array}{l}\text { dependent for } \\
\text { ADLs, interacts } \\
\text { minimally w } \\
\text { family }\end{array}$ \\
\hline 12 & 42 & GIV & ACOA & $\begin{array}{l}\text { frontal craniot, } \\
\text { clipping }\end{array}$ & $\begin{array}{l}\text { elevated TCDs PHD } \\
1,3,4\end{array}$ & $\begin{array}{l}\text { PB coma PHD 1; angioplasty } \\
\text { PHD } 3,4,5\end{array}$ & $\begin{array}{l}\text { Pneum onia, line } \\
\text { infection }\end{array}$ & $\begin{array}{l}\text { works as a wolun- } \\
\text { teer }\end{array}$ \\
\hline
\end{tabular}




\begin{tabular}{|c|c|c|c|c|c|c|c|c|}
\hline 13 & 44 & GII & $\begin{array}{l}\text { bilat ophth } \\
\text { carotid }\end{array}$ & rt GDC & $\begin{array}{l}\text { awoke hem iparetic; } \\
\text { urokinase rt MCA, } \\
\text { АCA, ICA }\end{array}$ & $\begin{array}{l}\text { repeat angioplasty, extrava- } \\
\text { sation of dye; PB begun }\end{array}$ & $\begin{array}{l}\text { cardiac dystunc- } \\
\text { tion, pneumonia }\end{array}$ & died \\
\hline 14 & 53 & Gll & ACOÁ & rt FT craniot & mild $\mathrm{rt}$ hemiparesis & $\begin{array}{l}\text { angioplasty of It ICA, MCA; } \\
\text { PHD } 4 \text { increased hem iparesis } \\
\text { PB hequn }\end{array}$ & $\begin{array}{l}\text { pneum onia, line } \\
\text { in fection }\end{array}$ & died PHD 7 \\
\hline 15 & 40 & F3GIV & ACOA & GDC & $\begin{array}{l}\text { IVC for hydroce phalus } \\
\text { progressive ICP }\end{array}$ & decom pressive craniot; PB & pneum onia & died \\
\hline 16 & 37 & Gl & $\begin{array}{l}\text { rt ICA bi- } \\
\text { furcation }\end{array}$ & $\begin{array}{l}\text { early wasospasm } \\
\text { PHD 9, rt FT } \\
\text { craniot }\end{array}$ & $\begin{array}{l}\text { drowsy postop; elevated } \\
\text { TCDs; frontal hemato- } \\
\text { ma rem oved }\end{array}$ & $\begin{array}{l}\text { elevated TCDs; PHD } 31 \text { VP } \\
\text { shunt; PHD } 32 \text { angioplasty } \\
\text { PHD } 33 \text { PB; PHD } 34 \text { reop for } \\
\text { frontal hematoma }\end{array}$ & $\begin{array}{l}\text { hypotension \& } \\
\text { vasospasm dur- } \\
\text { ing anesthesia. } \\
\text { for WP shunt }\end{array}$ & died \\
\hline 17 & 59 & F3GlV & distal $\mathrm{ACA}$ & $\begin{array}{l}\text { rt frontal craniot, } \\
\text { clipping }\end{array}$ & $\begin{array}{l}\text { elevated TCDs; } \mathrm{HHH}_{\text {i }} \\
\text { PHD } 2 \text { mild } \mathrm{EE}>\text { UE } \\
\text { paresis }\end{array}$ & $\begin{array}{l}\text { PHD } 4 \text { severel yele vated TCDS } \\
\text { angioplasty PHD } 5 \text {; obtunded } \\
\text { rt } \mathrm{ACA} \text {, supradinoid M1; PHD } 7 \\
\text { angioplasty ICP } 30-35 \text {, IVC, } \\
\text { PHD 8 PB }\end{array}$ & in tractable ICP & died PHD 9 \\
\hline 18 & 42 & F3GlV & It MCA & $\begin{array}{l}\text { GDC of MCA; } \\
\text { stuporous post- } \\
\text { op; } 8 \times 4-\mathrm{cm} \\
\text { hematoma. }\end{array}$ & PHD 3 PB begun & $\begin{array}{l}\text { in tractable ICP; PHD } 6 \text { increased } \\
\text { hematoma; OR flap remowed }\end{array}$ & & died PHD 8 \\
\hline 19 & 50 & GV & ACOÁ & $\mathrm{GDC}_{1} \mathrm{IVC} \times 2$ & $\begin{array}{l}\text { PB w/angiography } \\
\text { did not awaken }\end{array}$ & $\begin{array}{l}\text { angiography - extravasation of } \\
\text { dye; progressive increase in } \\
\text { IOP; IVC X2 }\end{array}$ & $\begin{array}{l}\text { in traventricular } \\
\text { hemomhage }\end{array}$ & died \\
\hline 20 & 38 & F3GIII & $\begin{array}{l}\text { rt oph- } \\
\text { thalmic }\end{array}$ & GDC & $\begin{array}{l}\text { rapid hemi plegia/ } \\
\text { aphasia; ratios It } 7.2 \text { / } \\
\text { rt } 8.7\end{array}$ & $\begin{array}{l}\text { angioplasty of tilat MCA, ICA, } \\
\text { EP } 1 \text { "after sym ptoms }\end{array}$ & $\begin{array}{l}\text { pneum onia, rash } \\
\text { arthralgia, cardi- } \\
\text { ac dystunction, } \\
\text { ALLI }\end{array}$ & independent \\
\hline 21 & 53 & F4GIII & ACOA & $\begin{array}{l}\text { rt FT craniot, } \\
\text { clipping }\end{array}$ & $\begin{array}{l}\text { decrease in LOC; ra- } \\
\text { tos rt } 4.6 \text { it } 1.6\end{array}$ & $\begin{array}{l}\text { angioplasty of it MCA; PB } 120 \\
\text { after decreased LOC }\end{array}$ & $\begin{array}{l}\text { ARDS, cardiac dys- } \\
\text { function, se psis, } \\
\text { ALI, MOD }\end{array}$ & died of Ml \\
\hline 22 & 42 & F5/GV & $\begin{array}{l}\text { It giant su- } \\
\text { pradinoid }\end{array}$ & GDC & $\begin{array}{l}\text { hemiplegia; ratios } \\
\text { rt } 10.0 \mathrm{At} 13.0\end{array}$ & $\begin{array}{l}\text { unatle to acoess; PB } 1 \text { " } \\
\text { after ele vated TCDs }\end{array}$ & $\begin{array}{l}\text { pneum onia; ARD, } \\
\text { ALI }\end{array}$ & $\begin{array}{l}\text { cared for by fam- } \\
\text { ily, aphasia; rt } \\
\text { hemiparesis }\end{array}$ \\
\hline 23 & 46 & F3GIII & $\begin{array}{l}\text { It ICA bifur- } \\
\text { cation }\end{array}$ & $\begin{array}{l}\text { microsurgical } \\
\text { clipping }\end{array}$ & $\begin{array}{l}\text { hemiplegia; ratios } \\
\text { It } 7.5 \mathrm{kt} 4.1\end{array}$ & angioplasty of It MCA PB 360 & $\begin{array}{l}\text { pneum onia; line in- } \\
\text { fection; A LI }\end{array}$ & $\begin{array}{l}\text { mono pare sis; lives } \\
\text { w'family }\end{array}$ \\
\hline 24 & 38 & $\mathrm{~F} 4 \mathrm{GlV}$ & It MCA & $\begin{array}{l}\text { microsurgical } \\
\text { clipping; IVC }\end{array}$ & $\begin{array}{l}\text { hemi paresis; ratios } \\
\text { It } 8.1 \text { kt } 6.1\end{array}$ & $\begin{array}{l}\text { angioplasty tilat MCA; PB 1" } \\
\text { after surgery (see case Illu- } \\
\text { stration) }\end{array}$ & $\begin{array}{l}\text { pneum onia; lobar } \\
\text { collapse, sepsis w' } \\
\text { line infection, ALI, } \\
\text { MOD, pancreati- } \\
\text { tis pleural efision, } \\
\text { joint swelling (ar- } \\
\text { thralgias) }\end{array}$ & $\begin{array}{l}\text { mild monoparesis; } \\
\text { li ves w' family }\end{array}$ \\
\hline 25 & 38 & F3GIII & ACOA & $\begin{array}{l}\text { microsumgical } \\
\text { clipping }\end{array}$ & aphasia, hemiplegia & $\begin{array}{l}\text { PB after } \mathrm{HHH} \text { for } 1 \mathrm{hr} \text {; angio- } \\
\text { plasty of It MCA }\end{array}$ & $\begin{array}{l}\text { pneum onia-ALI } \\
\text { SIRS/sepsis, } \\
\text { MOD }\end{array}$ & $\begin{array}{l}\text { independent, re- } \\
\text { turned to work }\end{array}$ \\
\hline 27 & 65 & $\begin{array}{l}\text { F4/GV; } \\
\text { GIV af- } \\
\text { ter IVC }\end{array}$ & ACOÁ & $\begin{array}{l}\text { GDC } w / \text { bilat } \\
\text { IVC }\end{array}$ & $\begin{array}{l}\text { TCD increase, MAP } \\
\text { increase }\end{array}$ & $\begin{array}{l}\text { PB } 2 \text { hrs, tilat MCA angio- } \\
\text { plasty }\end{array}$ & ARDS, MOD & $\begin{array}{l}\text { li ves at home, min- } \\
\text { im al assistance }\end{array}$ \\
\hline 28 & 42 & $\begin{array}{l}\text { F4/GW } \\
\text { GlV w } \\
\text { IVC }\end{array}$ & It MCA & GDC W/VC & $\begin{array}{l}\text { increased ICP, tem- } \\
\text { poral lobectomy, } \\
\text { craniectomy }\end{array}$ & $\begin{array}{l}\text { PB } 1 \text { hr, distal spasm, tilat } \\
\text { MCA, дС, РCA }\end{array}$ & $\begin{array}{l}\text { ARDS, MOD, } \\
\text { acute MI }\end{array}$ & $\begin{array}{l}\text { li ves at home, mod- } \\
\text { erate disatility, } \\
\text { im pro wing apha- } \\
\text { sia hemiparesis }\end{array}$ \\
\hline 29 & 46 & $\begin{array}{l}\mathrm{F} 4 / \mathrm{GW} \\
\text { GIV } w \\
\text { IVC }\end{array}$ & rt MCA & GDC WIVC & $\begin{array}{l}\text { increased } \mathrm{TCD} \text {, ICP } \\
\& \text { MAP }\end{array}$ & bilat MCA angioplasty & $\begin{array}{l}\text { SIRS w/sepsis } \\
\text { MOD }\end{array}$ & $\begin{array}{l}\text { independent, mi- } \\
\text { nimal assis- } \\
\text { tance }\end{array}$ \\
\hline 30 & 47 & F4ialv & $\begin{array}{r}\text { rt MCA } \\
\text { ACOA }\end{array}$ & microsumgical & $\begin{array}{l}\text { peak spasm on pre- } \\
\text { sentation }\end{array}$ & PB tilat MCA angioplasty & $\begin{array}{l}\text { sepsis, pneumo- } \\
\text { nia W'ALI }\end{array}$ & $\begin{array}{l}\text { moderate disability } \\
>3 \text { mos in inpa- } \\
\text { tient rehab }\end{array}$ \\
\hline \multicolumn{9}{|c|}{ 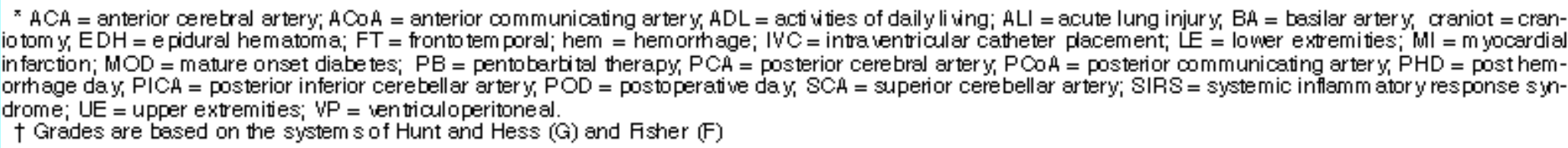 } \\
\hline
\end{tabular}

All patients underwent an initial evaluation, including review of outside angiographic or computerized tomography (CT) studies when not performed at our institution. These 32 patients in whom high-dose pentobarbital administration was part of combined therapy for the treatment of medically intractable vasospasm are a subpopulation of 528 patients with aneurysms treated by the senior author (R.H.R) in a 3-year period from July 1995 to 1998. All patients received conventional hypervolemic, hypertensive, hemodilution (HHH) therapy, with early use of pentobarbital combined with angioplasty and other measures to decrease intracranial pressure (ICP). If patients were rated Hunt and Hess Grade III or above and had hydrocephalus, they first underwent intubation and then placement of a ventriculostomy, arterial line, and a central line for subsequent Swan-Ganz catheterization (Fig. 1). Following diagnostic angiography, the senior author determined whether to proceed with endovascular coiling or with open microsurgical treatment. Endovascular coiling was reserved primarily for the treatment of patients with posterior circulation aneurysms, poor-grade patients, or elderly patients considered medically poor candidates for surgery. Other criteria for treatment included adequate vascular access for the guiding and microcatheters as well as the configuration of the 
aneurysm neck and associated branches of the parent artery. All patients underwent neuromonitoring and were transported to the neurosurgical intensive care unit where HHH therapy was instituted, and they were monitored for vasospasm and provided with medical support. The patient population consisted of 25 women and seven men, with ages ranging from 34 to 60 years (average 47 years). Modified Hunt and Hess grades at presentation were as follows: Grade 0, one patient; Grade I, three patients; Grade II, two patients; Grade III, nine patients; Grade IV, 10 patients; Grade V, seven patients. Sole treatment with microsurgical clipping was performed in 15 of 32 patients; endosaccular occlusion was performed in 17 of 20 patients; and two patients underwent combined treatment. Coil placement was used in endosaccular aneurysms in poor-grade patients (four anterior communicating artery, one bilateral carotid-ophthalmic, one carotid-ophthalmic, one posterior communicating artery, five middle cerebral artery [MCA], and one giant supraclinoid carotid), for posterior circulation aneurysms (two basilar artery, two posterior inferior cerebellar artery aneurysms), or in patients with multiple medical illnesses who were unlikely to survive surgical intervention. Patients underwent transcranial Doppler (TCD) ultrasound twice daily. Cardiac output was maximized according to individual starting curves determined by Swan-Ganz catheter measurements. Early pentobarbital therapy was instituted within 2 hours in patients whose neurological deficits persisted despite HHH therapy. A loading dose of 2 to $5 \mathrm{mg} / \mathrm{kg}$ was used with continuous electroencephalographic monitoring to maintain burst suppression with between four and six cortical spikes per minute (Table 2). Patients received fluids and pressors preoperatively, if necessary, to avoid hypotension. Subsequent angioplasty was performed in 26 of 32 patients. Additionally, all 32 patients underwent treatment for increased ICP with ventriculostomy placement, removal of the bone flap (11 patients), evacuation of associated intracranial hematoma (five patients), or decompressive lobectomy (four patients).

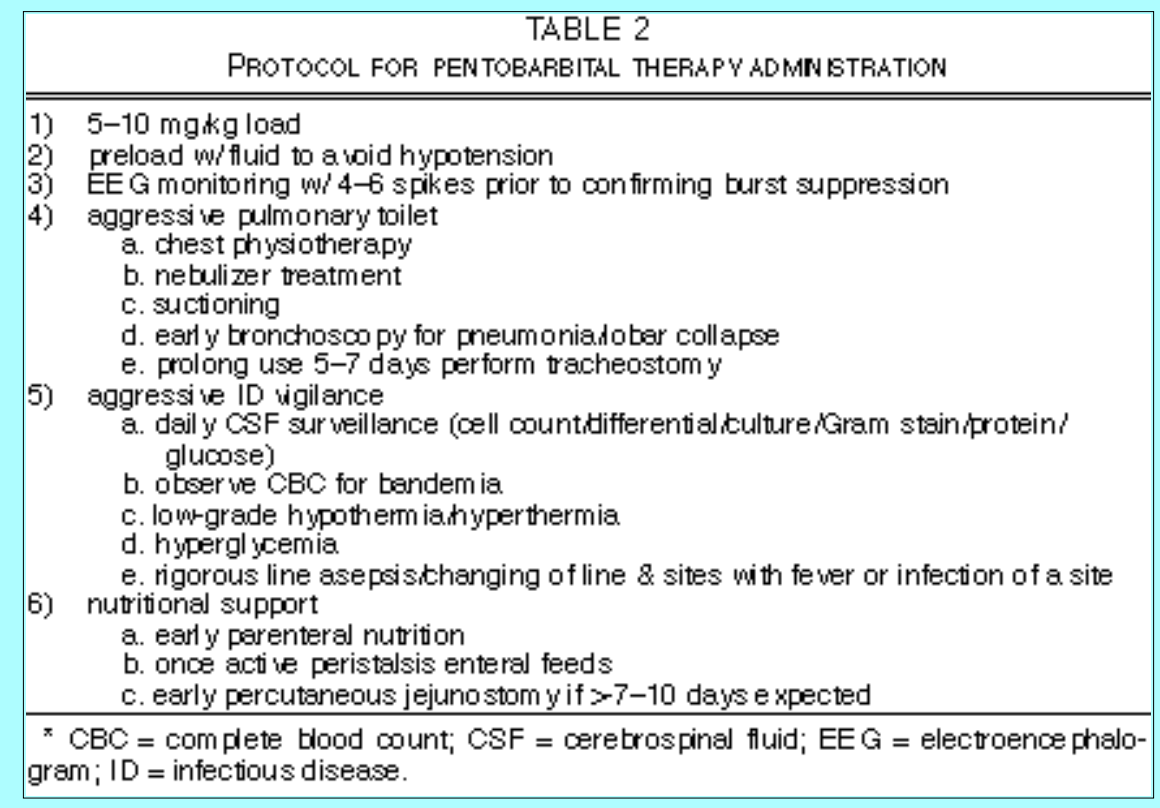

\section{ILLUSTRATIVE CASES}

\section{Case 20}

This 38-year-old woman with Hunt and Hess Grade III and Fisher Grade 3 aneurysmal SAH underwent Guglielmi detachable coil (GDC) treatment of her right ophthalmic artery aneurysm (Fig. 1 upper left and right). 

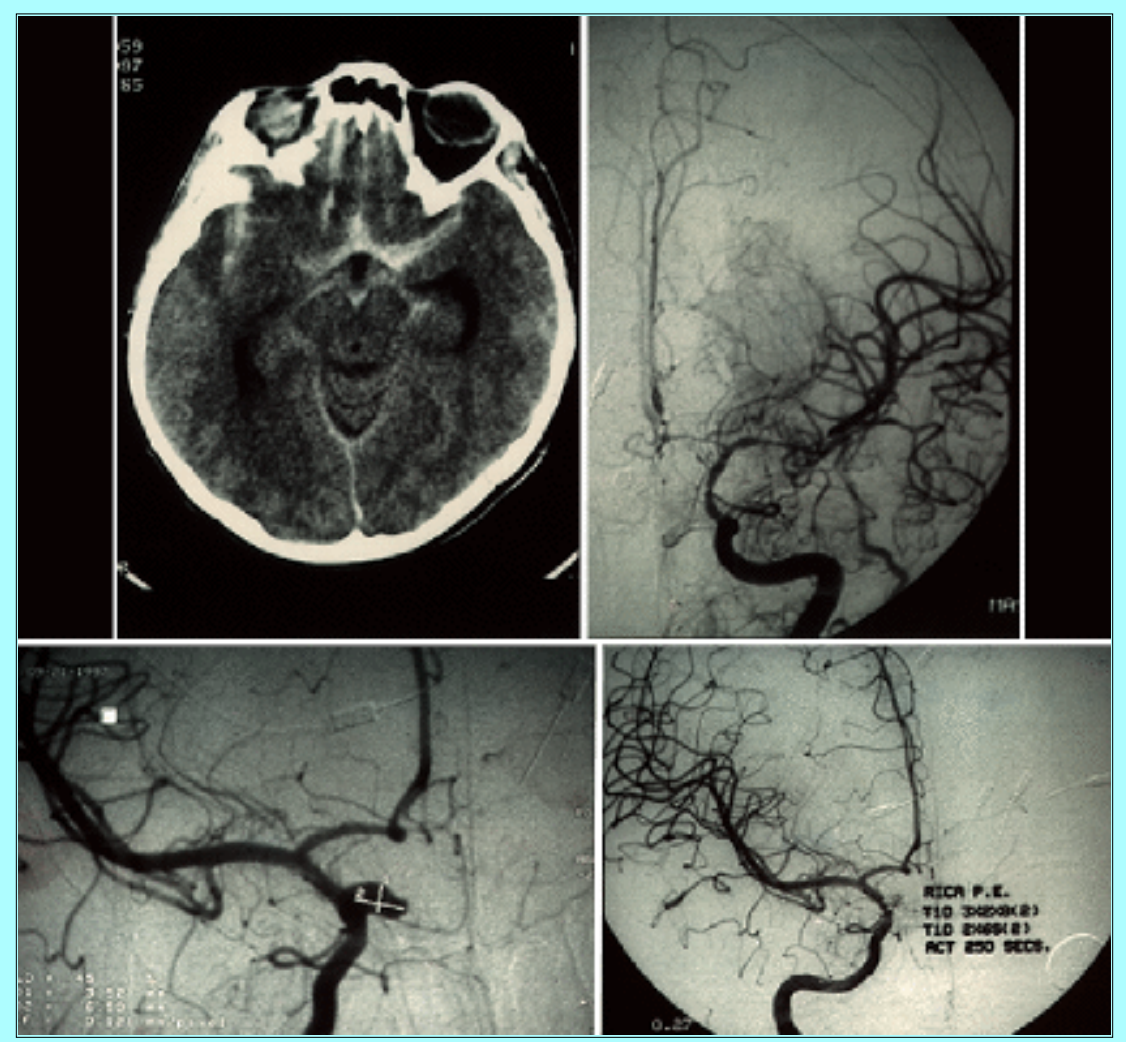

Fig. 1. Case 20. Imaging studies. Upper Left: Digital subtraction right ICA angiogram with right orbital oblique view demonstrating a carotid-ophthalmic artery aneurysm. Measurements of aneurysm used to select initial coils. Upper Right: Angiogram obtained after initial endovascular treatment (postendovascular occlusion of aneurysm) with an activated clotting time (250 seconds) twice baseline. Lower Left: Initial CT scan demonstrating Fisher Grade 3 SAH with dilation of temporal horns. Lower Right: Angiogram demonstrating severe vasospasm of left supraclinoid carotid, $\mathrm{M}_{1}$ segment, and $\mathrm{A}_{1}$ segment now with medically intractable vasospasm with clinical aphasia and hemiplegia.

She received HHH therapy because of evidence of elevated blood flow velocity detected on TCD ultrasonography posthemorrhage (PH) Day 3 (mean blood flow velocity in the right MCA increased from 96 to 161 to $224 \mathrm{~cm} / \mathrm{second}$ and in the left MCA it increased from 102 to 155 to 220 on PH Day 5.) Clinically, she remained asymptomatic until PH Day 7; at which time she became diaphoretic, aphasic, and had loss of antigravity strength in the right upper extremity. The TCD ratios measured in the right MCA were 7.2 to 8.5 to 9.1 and the right MCA mean blood flow velocities were $255 \mathrm{~cm} / \mathrm{second}$; in the left MCA, TCD ratios were 3.9 to 9.3 to 8.0 and left MCA mean velocities were 207 $\mathrm{cm} / \mathrm{second}$. Her clinical status improved after receiving aggressive HHH therapy. On PH Day 9 the patient experienced a repeated episode of hemiplegia and aphasia; her mean arterial pressure was 107 to $111 \mathrm{~mm} \mathrm{Hg}$ and she was treated with $250 \mathrm{ml}^{3}$ of $5 \%$ albumin. Strength increased to $4 / 5$ in the right upper extremity and $3 / 5$ in the left lower extremity. Several hours later her right side worsened to hemiplegia and aphasia. Pentobarbital was administered and emergency CT scanning was performed. Ventriculostomy and cerebral angiography were performed, which demonstrated severe bilateral vasospasm of the internal carotid arteries, and MCAs, more on the left than right. Angioplasty was performed in the left $\mathrm{M}_{1}$ segment, supraclinoid carotid, and right supraclinoid carotid arteries (Figs. 1 lower left and right and 2 upper left). 

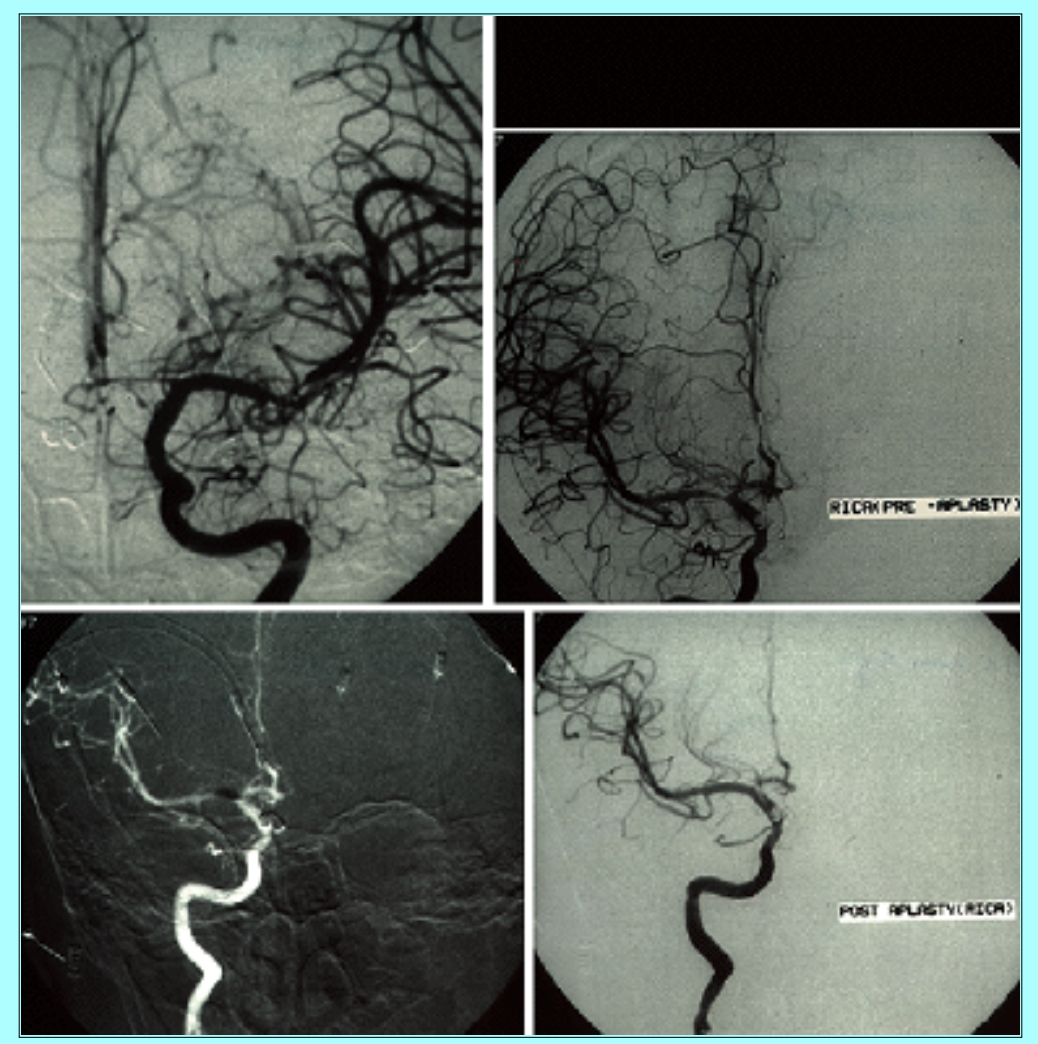

Fig. 2. Case 20. Upper Left: Controlled angiogram immediately after ballon dilation of left $\mathrm{M}_{1}$ segment and left supraclinoid carotid. Upper Right: Angiogram demonstrating persistent vasospasm of right MCA. Lower Left: Digital subtraction angiogram in which the roadmapping technique is used showing microballoon dilated in the right $\mathrm{M}_{1}$ segment . Lower Right: Controlled angiogram of right ICA immediately after angioplasty.

Postprocedure, the patient remained in a pentobarbital-induced coma for 3 days, which was progressively decreased by $25 \%$ each postprocedure day. Transcranial Doppler ultrasonography was performed postprocedure. On postoperative Day 1, TCD ratios were: left MCA 2.3 (mean MCA velocity $88 \mathrm{~cm} / \mathrm{second}$ ) and right MCA 3.1 (mean MCA velocity $136 \mathrm{~cm} / \mathrm{second}$ ). Over the following 7 days the right-sided TCD ratios progressively increased. The patient did not tolerate HHH therapy, with decreased cardiac contractility (cardiac ejection fraction 57-35\%). On PH Day 23, repeated angiography was performed because the patient was not tolerating HHH therapy and had persistent right MCA ratios of between 5 and 7. Angioplasty was performed in the stenotic right $\mathrm{M}_{1}$ segment (Fig. 2 upper right and lower left and right). Comorbidity features included acute lung injury with pneumonia, pulmonary edema, decreased cardiac contractility, and inflammatory arthritis of the right foot/ankle/toe. The patient's cardiac dysfunction resolved after discontinuation of HHH therapy. She was progressively weaned, extubated, and discharged home for outpatient rehabilitation. Currently, the patient lives at home and has returned to work at her 3-month follow up.

\section{Case 24}

This 38-year-old woman presented with Hunt and Hess Grade IV SAH from a ruptured left MCA aneurysm, as well as with sylvian fissure hematoma and hydrocephalus (Fig. 3 A-B). 


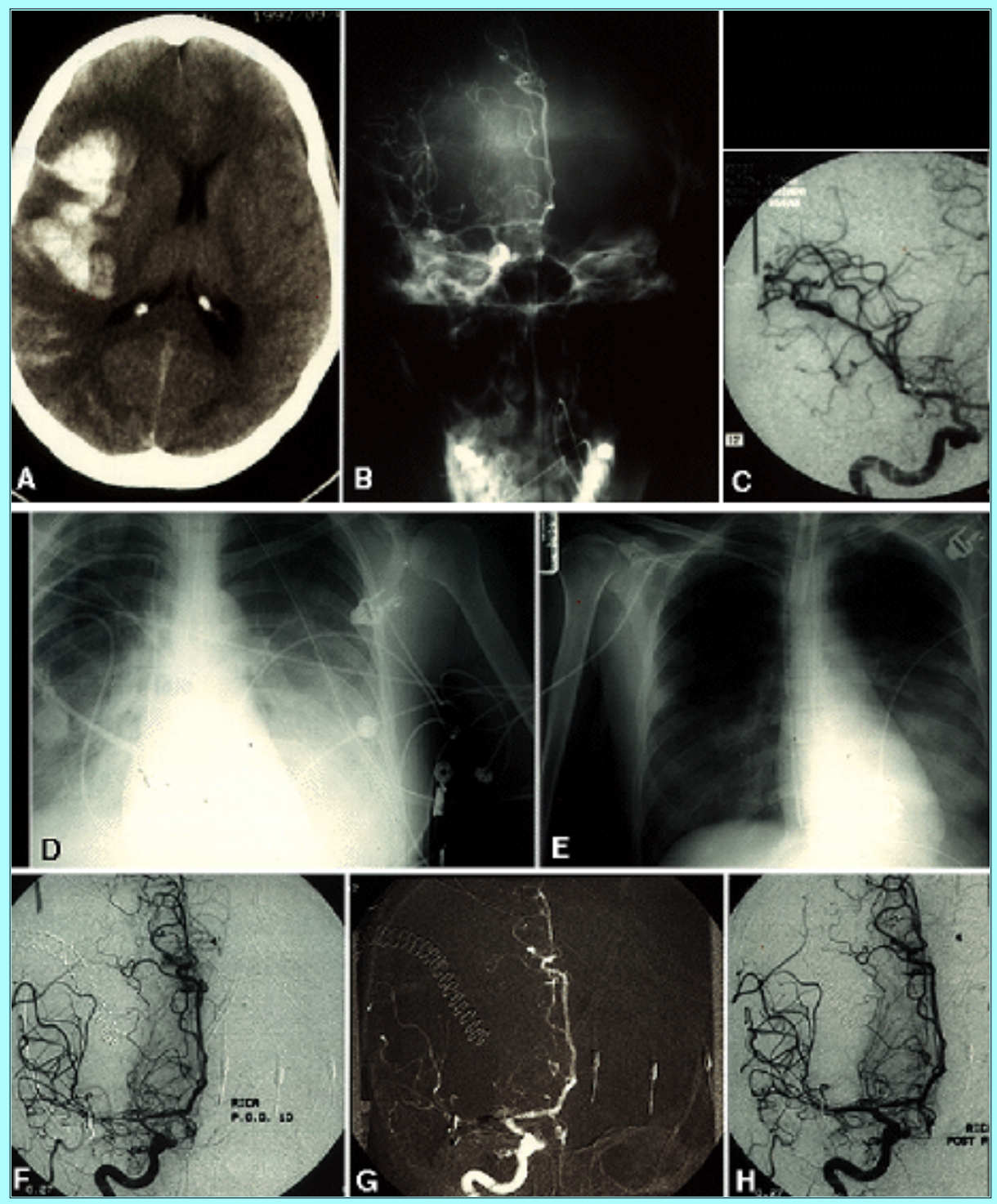

Fig. 3. Case 24. A: Computerized tomography scan at presentation demonstrating Fisher Grade 4 SAH and sylvian fissure hematoma. B: Preoperative angiogram from an outside institution demonstrating a right MCA aneurysm. C: Intraoperative angiogram demonstrating obliteration of the aneurysm and normal filling of superior and inferior trunks. D: Postoperative x-ray film of the chest, during a period of severe respiratory distress, demonstrating alveolar consolidation in four lung quadrants. E: Subsequent X-ray film of the chest demonstrating evidence of marked improvement after tracheostomy and bronchoscopy. F: Angiogram revealing severe cerebral vasospasm that is affecting the right supraclinoid carotid artery and right $\mathrm{M}_{1}$ segment. $\mathrm{G}$ : Angiogram demonstrating balloon angioplasty of the right supraclinoid carotid artery and $\mathrm{M}_{1}$ segment. $\mathrm{H}$ : Control angiogram immediately after balloon angioplasty demonstrating increased lumen diameter.

On admission, she underwent intubatation, was experiencing contralateral hemiparesis, and also underwent a ventriculostomy. A left frontotemporal craniotomy and microsurgical clipping of the left MCA aneurysm were performed. Intraoperative angiography confirmed aneurysm clipping and normal filling of the superior and inferior trunks (Fig. 3C). Due to significant cerebral edema, pentobarbital therapy was initiated; the bone flap was left out and the dura left open. The patient remained in a pentobarbital-induced coma and ICP was controlled using ventricular drainage. On postoperative Day 3, she developed hypoxia and required increased positive end-expiratory pressure, fraction of inspired oxygen, and aggressive pulmonary toilet. There was evidence of early pancreatitis with pleural effusion and hypoxia on postoperative Day 4, and the patient was continued on bowel rest with hyperalimentation via total parenteral nutrition. On postoperative Day 6 she developed increased ICP to $22 \mathrm{~mm} \mathrm{Hg}$ and increased cerebrospinal fluid output. Computerized tomography scanning revealed no new hemorrhage or ventriculomegaly. Transcranial Doppler ultrasonography demonstrated increased right-sided velocities from means of 130 to $160 \mathrm{~cm} / \mathrm{second}$ with ratios increased from 2.0 to 5.0 on the right. Her pulmonary insufficiency was worsening, and an x-ray film of the chest demonstrated lobar collapse with pneumonia (Fig. 3D). Subsequently, she underwent emergency bronchoscopy and tracheostomy (Fig. 3E). On PH Day 10, while receiving pentobarbital therapy, she had significantly elevated blood flow ratios, which increased from 3.9 to 7.9 on the right and from 3.2 to 4.1 on the left; mean right MCA velocities increased from 138 to $205 \mathrm{~cm} / \mathrm{second}$ and then to $220 \mathrm{~cm} / \mathrm{second}$.

Angiography was performed, which revealed evidence of vasospasm of the bilateral $\mathrm{M}_{1}$ segment (Fig. 3F). She underwent angioplasty (Fig. 3 F-G); postangioplasty her TCD measurements showed a reduced mean right MCA velocity of $143 \mathrm{~cm} / \mathrm{second}$ and a left MCA velocity of 112 $\mathrm{cm} / \mathrm{second}$; a mean right MCA ratio of 4.9 and left MCA ratio of 2.0. Pentobarbital therapy was progressively decreased over the next 5 days, with improved pulmonary toilet, aggressive chest physiotherapy and nebulizers. Subsequently, she was discharged to inpatient rehabilitation. 
Progressive improvement was noted at 6-week and 12-week follow-up examination. Currently, she is doing well at 10 months postoperatively and her autologous bone flap was replaced. She has no focal neurological deficits and has returned to a regular work schedule.

\section{Case 22}

The patient was a 42-year-old male jockey, who suffered SAH while riding his horse. He fell to the ground and experienced a seizure, respiratory arrest, and had a likely aspiration. He was resuscitated and remained unresponsive in a coma at initial assessment (Hunt and Hess Grade V). Computerized tomography scanning of the head demonstrated evidence of diffuse SAH, hydrocephalus, and a 3.5-cm mass revealed as the giant aneurysm (Fig. 4A).
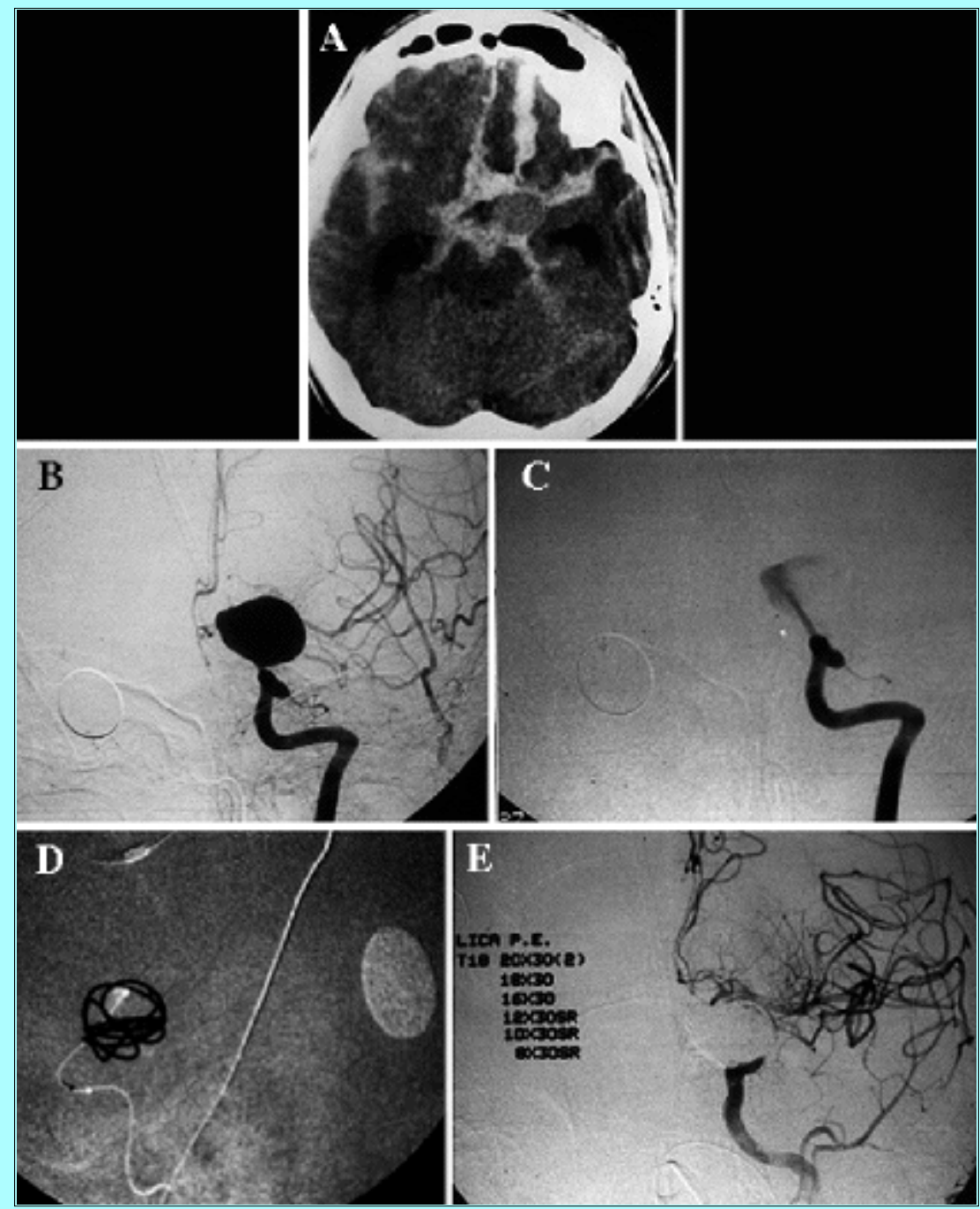

Fig. 4. Case 23. Imaging studies. A: Computerized tomography scan at presentation demonstrating Fisher Grade 4 SAH with a globoid hematoma representing a giant supraclinoid aneurysm. B: Left digital subtraction angiogram demonstrating giant supraclinoid aneurysm (unable to discern a discrete neck in this view). C: Early-phase angiogram, demonstrating a jet of contrast material, which suggests a narrow aneurysm neck. D: Deployment of initial coils, stable position achieved without displacement into the ICA, $\mathrm{M}_{1}$, or $\mathrm{A}_{1}$ segments. E: Control angiogram demonstrating obliteration of aneurysm and filling of $\mathrm{A}_{1}$ and $\mathrm{M}_{1}$ segments and their respective branches.

Angiography confirmed a giant left supraclinoid artery aneurysm (Fig. 4B). Ventriculostomy was placed, and his neurological status improved to a Hunt and Hess Grade IV. Due to pulmonary aspiration, he developed pneumonia and subsequently adult respiratory distress syndrome (ARDS), requiring pressure-controlled ventilation. On PH Day 4, he had a significant increase in his TCD measurement, increased CSF drainage via his ventriculostomy and elevated ICP to $20 \mathrm{~mm} \mathrm{Hg}$. The TCD values increased from PH Day 3 to PH Day 5 (right MCA mean velocities of 83 to 151 to 183 to 227 to $255 \mathrm{~cm} / \mathrm{second}$ and left MCA mean velocities 133 to $200 \mathrm{~cm} / \mathrm{second}$ ); over the same period TCD ratios increased (right 3.3-10.3; left 5.2-13.3). Repeated angiography confirmed severe bilateral vasospasm of both $\mathrm{M}_{1}$ vessels and the supraclinoid carotid artery, as well as of the bilateral $\mathrm{A}_{1}$ segments. Because of the presence of an untreated ruptured giant aneurysm, he was not a candidate for angioplasty or papaverine therapy. He was placed in pentobarbital-induced coma and aggressively treated for his aspiration pneumonia and ARDS. Tracheostomy and bronchoscopy were performed to improve oxygenation and pulmonary toilet. Moderate HHH therapy was continued as tolerated. On PH Day 8, endovascular exploration of the aneurysm was performed, which demonstrated a small-neck aneurysm that made GDC treatment of the aneurysm possible (Fig. 4C-E). Attempts to perform angioplasty in the left $\mathrm{M}_{1}$ segment were thwarted by the mass effect from the giant aneurysm fundus. The patient was progressively weaned from his pressure-support 
ventilation, and pentobarbital therapy was decreased over a 4-day period without increase in his ICP. Currently, the patient lives at home, interacting with his family and requiring only partial assistance with activities of daily living. He is nonambulatory but beginning to stand and has moderate aphasia.

\section{Case 26}

This 33-year-old man presented with a Hunt and Hess Grade V SAH resulting from rupture of a basilar bifurcation aneurysm (Fig. 5A-B).

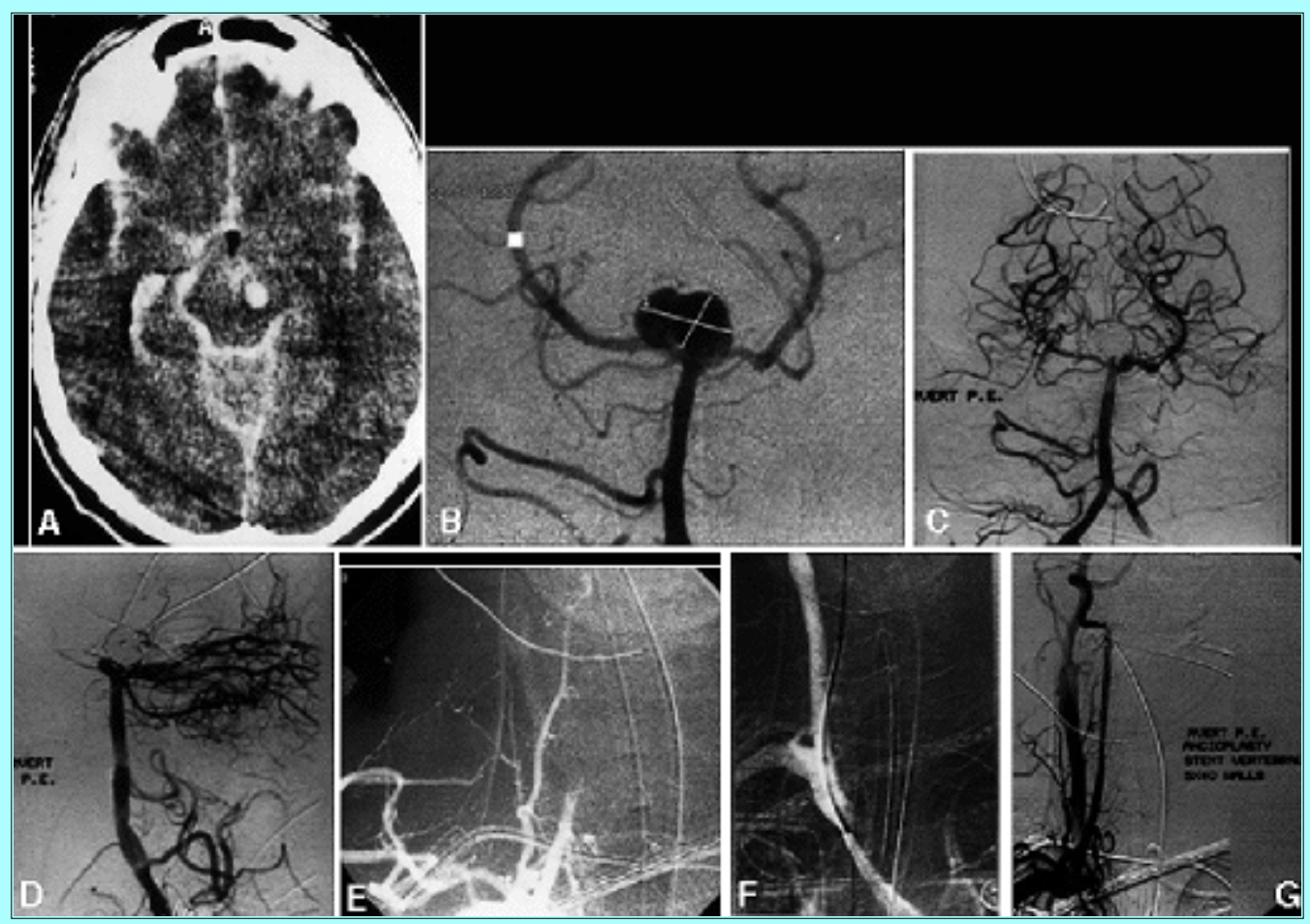

Fig. 5. Case 25. Imaging studies. A: A CT scan demonstrating diffuse SAH with interpeduncular hematoma and hydrocephalus and rehemorrhage in the cerebral peduncle before treatment. B: Angiogram demonstrating evidence of complex basilar bifurcation aneurysm with bilobed configuration. C and D: Angiograms obtained prior to coil placement. Anteroposterior (C) and lateral (D) views, demonstrating obliteration of aneurysm and normal filling of the PCAs (accomplished using ballon remodeling techniques). E: Posthemorrhage Day 8 angiogram demonstrating dissection of the right vertebral artery and posterior circulation spasm. F and G: Control angiograms after angioplasty and stenting of dissection (F), and after undergoing basilar artery angioplasty $(\mathrm{G})$ for associated vasospasm.

The patient improved to Grade IV following placement of a ventriculostomy. Because of increased ICP, a CT scan was obtained, which demonstrated evidence of new hemorrhage into the cerebral peduncle. The patient had progressive pulmonary distress with oxygen desaturation and underwent emergency bronchoscopy for lobar collapse. Posthemorrhage Day 3, he underwent GDC treatment of the aneurysm, with balloon remodeling techniques (Fig. 5C-D). Elevated TCD values were noted on PH Day 3. He underwent balloon angioplasty of the anterior circulation and was placed in pentobarbital-induced coma. Posthemorrhage Day 8 , he had $\mathrm{SjVO}_{2}$ changes that demonstrated increased oxygen extraction consistent with an oligemic state. Posterior circulation TCD values were elevated; a repeated CT scan was obtained that revealed bilateral hypodensities of the PCAs. A cerebral angiogram demonstrated an occluded right vertebral artery (Fig. 5E). Emergency vertebral artery angioplasty with stent placement was performed, followed by basilar artery angioplasty (Fig. 5F-G). His course was complicated by pneumonia, sepsis, pancreatitis, and prolonged intubation. He underwent placement of a ventriculoperitoneal shunt and, following a prolonged intensive care unit course, he was transferred to rehabilitation. At 3-month follow-up review he had recovered substantially; he was living independently and was cutting his lawn and cleaning the family swimming pool.

\section{RESULTS}

Twenty-one patients survived and 11 died after undergoing treatment using this protocol (Table 1); associated morbidity factors included pneumonia with acute lung injury (18 patients) and fulminant ARDS (six patients), sepsis (16 patients), pancreatitis (five patients), cardiac dysfunction (three patients), and septic arthritis and pulmonary embolus (one patient each). Infectious complications were monitored by closely following the differential white-cell count, early use of tracheostomy and aggressive pulmonary toilet (Case 24). Of the 21 survivors, seven have returned to work, live independently, and have no neurological deficits; eight require mild assistance at home; four are in rehabilitation and have moderate deficits at 3 months; and two remain in a vegetative state. Factors associated with a poor outcome include a delay of more than 2 hours in recognition or intervention for vasospasm (Cases 8, 9, and 16; Table 1), associated morbidity factors related to preexisting medical condition combined with pentobarbital therapy (Case 21), branch occlusion with vessel rupture (Case 13), and intractable ICP related to small-vessel vasospasm (Cases 14 and 15). In a selected group of poor-grade patients, a single cause could not be identified and was likely related to the patient's poor clinical grade (Cases 18 and 19).

\section{DISCUSSION}


The common goal in treating vasospasm in patients with symptomatic SAH involves minimizing the neuronal injury. Approaches are directed toward two major avenues, including improving cerebral blood flow (CBF) as well as reducing cellular energy demands, thereby avoiding a demand/supply mismatch that results in irreversible neuronal injury.[2] Improving CBF is accomplished by a host of different techniques, including standard $\mathrm{HHH}$ therapy, ventricular drainage, and more novel invasive techniques that include removal of the craniotomy flap, as well as cerebral angioplasty. Cellular energy demands are minimized during periods of oligemia by hypothermia, seizure prophylaxis, and avoiding hypoxia, acidosis, and hyperglycemia as well as providing neuroprotection.

It is important to note that standard HHH therapy is not without risk, as demonstrated by patients in Cases 20 and 21 . Authors of other studies have reported complication rates of pulmonary edema (7-17\%), myocardial infarction (2\%), coagulopathy (3\%), and dilutional hyponatremia (3-35\%).[8, 9] Because of underlying cardiac dysfunction, neither of these two patients (Cases 20 and 21) tolerated HHH therapy. The patient in Case 20 developed severe loss of cardiac contractility amd rapidly developed cardiac failure at low-filling pressures. The patient in Case 21 sustained a myocardial infarction resulting in electromechanical dissociation and death. When faced with a patient with both poor cardiac function and advanced age, it may be necessary to consider a less toxic therapy than HHH treatment and avoid pentobarbital therapy unless an absolutely life-threatening condition exists. It is also well reported that poor-grade SAH patients have a higher incidence of acute lung injury.[5] The modalities used to treat pulmonary insufficiency may also compromise the treatment of vasospasm (Table 3).

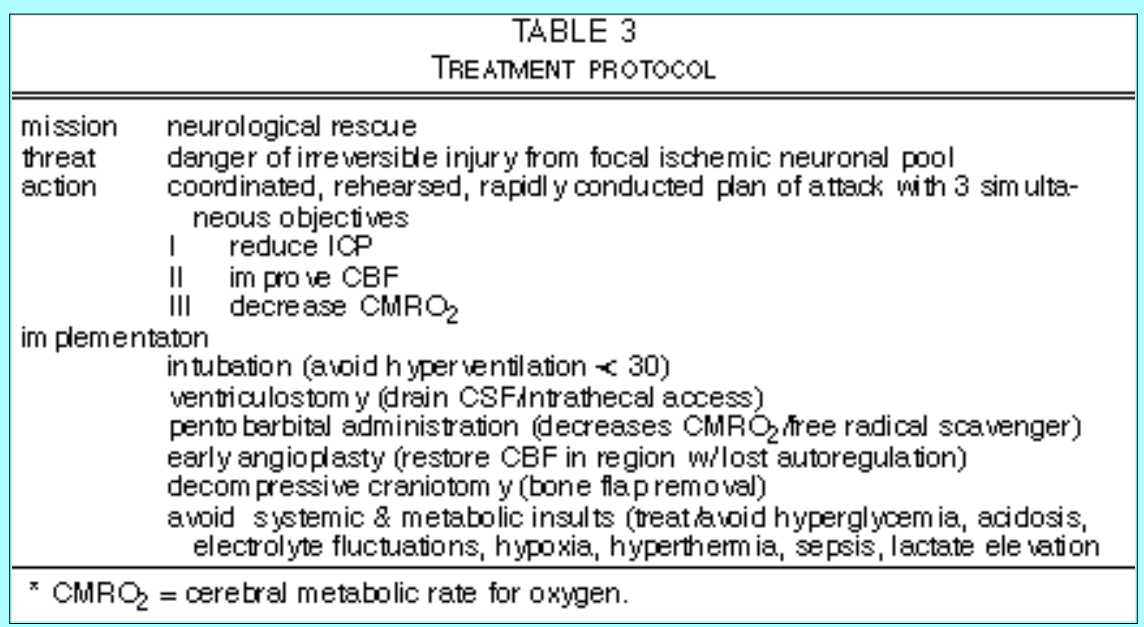

Currently, our trend is toward early performance of angioplasty and use of pentobarbital therapy only when distal spasm predominates in the face of elevated ICP.

Pentobarbital therapy is only one aspect used in the emergency treatment response to symptomatic medically intractable vasospasm. Its use includes rapidly coordinated and rehearsed protocols for restoring CBF. Pentobarbital not only reduces cerebral metabolic oxygen rate[2] until electrical silence is obtained (equating with a 50\% decrease in cerebral metabolic oxygen rate), but also enhances the binding of gamma-aminobutyric acid, an inhibitory neurotransmitter, thereby reducing excitotoxicity and increased energy

expenditure. $[1,4,6,7,9,12,14,15]$ One of the most important modes of action of pentobarbital is as a free radical scavenger that reduces the lipid peroxidation of the neuronal cell membrane and intracellular organelles.[10,11]

Experience with combined endovascular therapy and pentobarbital is limited. In a recent study,[4] 18 patients with medically intractable vasospasm who underwent endovascular therapy were divided into two equal groups; one group was treated with combined therapy using thiopental, whereas the other group only underwent endovascular therapy. A more favorable outcome was seen in the barbiturate adjunctive group in which five of nine improved to good recovery; one had mild deficit, and one died. These patients also underwent jugular-bulb monitoring, with subsequent improvement in the arteriovenous lactate difference and in cerebral oxygen extraction with restoration of normal coupling of CBF and oxygen consumption. In the control arm, two of nine patients had good recovery, two had mild deficit, four had severe deficit, and one died. The authors concluded that this protocol should be used as a last-line therapy for intractable vasospasm.[4]

Timing and indications for barbiturate protection remain controversial. Proponents of barbiturate protection agree that best results are achieved when burst suppression occurs prior to the ischemic insult. This is not practical for the unpredictable nature of vasospasm. However, it is agreed that beyond 3 hours a deleterious effect is noted in experimental models.[10,11,16] Barbiturate therapy may be replaced by early use of pentobarbital in the face of intractable vasospasm, especially when accompanied by increased ICP or distal spasm not likely to respond to proximal angioplasty. Our results support early ( $<2$ hours) initiation of pentobarbital therapy before a deficit becomes irreversible.

The neurovascular uses of pentobarbital have included neuroprotection during temporary aneurysm clipping, carotid endarterectomy, hypothermic cardiac arrest, and vascular bypass surgery. Early experience with pentobarbital therapy for the treatment of vasospasm produced poor results. Kassell, et al.,[8] have reported on 12 patients who were treated with high-dose pentobarbital; three of these patients initially benefited, although two of them eventually died, and nine additional patients died as well. The surviving patient was left with paraparesis. Other experiences with pentobarbital therapy and vasospasm are summarized in Table 4. These experiences all have a common element: neuronal protection was established without restoration of CBF. Our experience has differed because of the two-pronged attack to restore $\mathrm{CBF}$ and protect the compromised neuronal pool. Integrating reduction of ICP (ventriculostomy and craniectomy) and restoring $\mathrm{CBF}$ with angioplasty has resulted in a successful neurological rescue; the lives of 21 of 32 patients have been saved and, most importantly, seven 
of these 21 patients have returned to independent living; only eight patients require minimal assistance with daily activities, and four patients are moderately disabled at less than 3 months posthemorrhage. We are encouraged by these results, but we also feel remiss about the two patients who remain vegetative survivors. Their tremendous loss in quality of life and their emotional, financial, and personal devastation have driven us to seek new means to improve outcome with earlier therapies and to pursue new treatment modalities.

\begin{tabular}{|c|c|c|c|}
\hline \multicolumn{4}{|c|}{$\begin{array}{c}\text { TABLE } 4 \\
\text { SUMMARY OF STUDIES IN WHICH PATIENTS RECEIVED BARBTURATE THERAPV IN THE TREATMENT OF } \\
\text { CEREBRAL YASOSPASMt }\end{array}$} \\
\hline Authors \& Year & $\begin{array}{l}\text { No. of } \\
\text { Patients }\end{array}$ & Treatment & Outcome \\
\hline Hashi \& Tanaka, & 6 & $\begin{array}{l}\text { secobarbital } 10 \mathrm{mg} k \mathrm{~kg}, \\
3 \text { patients for } 14 \text { days }\end{array}$ & $\begin{array}{l}2 \text { dead, } 1 \text { uegetative, } 3 \text { im proved } \\
\text { whout deficits }\end{array}$ \\
\hline $\begin{array}{l}\text { Kassell, et al., } \\
1980\end{array}$ & 12 & $\begin{array}{l}15-30 \mathrm{mg} k g \text { load, } \\
2 \text { mg kghr main- } \\
\text { tenanoe }\end{array}$ & $\begin{array}{l}9 \text { dead; } 3 \text { improved (2 died, } 1 \text { improved } \\
\text { then deteriorated w/ paraparesis) }\end{array}$ \\
\hline $\begin{array}{l}\text { Sam som \& Beyer, } \\
1980\end{array}$ & 7 & thiopental $<72 \mathrm{hrs}$ & $\begin{array}{l}\text { none im proved; } 4 \text { dead; } 1 \text { wegetati ve; } \\
\text { wegetati ve; } 2 \text { major deficits; } 4 \text { patients } \\
\text { discontinued, not tolerating drug }\end{array}$ \\
\hline $\begin{array}{l}\text { 'Woodoock, et al., } \\
1982\end{array}$ & 5 & pento Larbital & $\begin{array}{l}1 \text { (secondary to AVM) im pro ved; } 4 \text { died } \\
\text { of intractable ICP }\end{array}$ \\
\hline current study & 32 & $\begin{array}{l}5-10 \text { mgkgidoad } 4-6 \\
\text { spikestmin com bined } \\
\text { wiloP reduction \& } \\
\text { angioplasty }\end{array}$ & $\begin{array}{l}21 \text { survi wors, } 7 \text { return to work, } 8 \text { minim al } \\
\text { deficit, } 4 \text { at home w/moderate assis- } \\
\text { tance } w / \text { ADLs, } 2 \text { wegetative }\end{array}$ \\
\hline
\end{tabular}

The early use of cerebral angioplasty has provided tremendous gains in the treatment of delayed cerebral vasospasm when it involves proximal cerebral arteries. Eskridge and Song [3] reported the use of balloon angioplasty in more than 150 patients who were typically treated within a time window of 12 to 18 hours. In a selected group of 52 patients, they identified the superior results of balloon angioplasty when compared with papaverine therapy; 39 patients underwent angioplasty and 13 papaverine therapy. Only one vessel of 101 treated in the angioplasty group required retreatment with balloon angioplasty, whereas in the papaverine group $42 \%$ required retreatment. The time period for intervention and the pattern of vasospasm (proximal, distal, diffuse) was not specified. In a study of 93 patients who underwent angioplasty, Rosenwasser and coworkers (unpublished data), reported a 70\% sustained clinical improvement in 51 patients treated within 2 hours but only a $40 \%$ sustained improvement in 33 patients treated after 2 hours. Time and location of spasm play a key role in determining the likelihood of response to endovascular techniques. Distal spasm is the most recalcitrant to endovascular treatment. Although balloon angioplasty is effective in dilating the proximal arteries, papaverine therapy used for distal spasm has a very short half-life, requiring frequent retreatment. The hazards of papaverine therapy are numerous, including crystalization, hypotension, intractable ICP, and hemorrhagic transformation of cerebral infarctions. Currently, no single agent is effective at long-term reversal of distal vasospasm, although there are several agents on the horizon awaiting clinical trials to prove their effectiveness (unpublished data)

In the battle against vasospasm, a rapid, coordinated intervention to protect the neuronal pool and restore blood flow must occur if worthwhile survival is to be attained. Ultimately, the lessons learned from earlier use of pentobarbital therapy demonstrated that when used alone it is not the solution. Restoring CBF and reducing ICP must occur in tandem before a completed infarct occurs. Pulmonary and cardiac complications associated with pentobarbital use should be anticipated and cardiopulmonary function should be optimized with oximetric Swan-Ganz monitoring and early tracheostomy and bronchoscopy for pulmonary toilet. Our experience does support the tailored use of pentobarbital therapy combined with CBF restoration. Despite the best equipment, medicines and expertise, one must race against the clock to salvage an ischemic neuronal pool and avoid the tragedy of patients enduring in vegetative state.

\section{References}

1. Belopavlovic M, Buchthal A, Beks JWF: Barbiturates for cerebral aneurysm surgery. A review of preliminary results. Acta Neurochir 76:73-81, 1985

2. Cruz J: The first decade of continuous monitoring of jugular bulb oxyhemoglobin saturation: management strategies and clinical outcome. Crit Care Med 26:344-351, 1998

3. Eskridge JM, Song JK: A practical approach to the treatment of vasospasm. AJNR 18:1653-1660, 1997

4. Fandino J, Weiser HG, Krayer S, et al: Barbiturate coma for intractable cerebral vasospasm after aneurysmal subarachnoid hemorrhage. J Neurosurg 88:192A, 1998 (Abstract)

5. Gruber A, Reinprecht A, Görzer H, et al: Pulmonary function and radiographic abnormalities related to neurological outcome after aneurysmal subarachnoid hemorrhage. J Neurosurg 88:28-37, 1998

6. Hashi K, Tanaka K: Barbiturate coma for severe brain ischemia due to cerebral vasospasm, in Wilkins RH (ed): Cerebral Arterial Spasm. Baltimore: Williams \& Wilkins, 1980, pp 637-645

7. Hoff JT, Nishimura M, Newfield P: Pentobarbital protection from cerebral infarction without suppression of edema. Stroke 13:623-628, 1982 
8. Kassell NF, Peerless SJ, Drake CG, et al: Treatment of ischemic deficits from cerebral vasospasm with high dose barbiturate therapy. Neurosurgery 7:593-597, 1980

9. Kofke WA, Yonas H, Wechsler L: Neurologic intensive care, in Albin MS (ed): Textbook of Neuroanesthesia With Neurosurgical and Neuroscience Perspectives. New York: McGraw-Hill, 1997, pp 1247-1347

10. Nehls DG, Spetzler RF: A review of cerebral protection against ischemia: Part 1. BNI Q 2:1823, 1986

11. Nehls DG, Todd MM, Spetzler RF, et al: A comparison of the cerebral protective effects of isoflurane and barbiturates during temporary focal ischemia in primates. Anesthesiology 66:453-464, 1987

12. Piatt JH Jr, Schiff SJ: High dose barbiturate therapy in neurosurgery and intensive care. Neurosurgery 15:427-444, 1984

13. Samson DS, Beyer CM: Thiopental coma in the treatment of vasospasm induced cerebral ischemia/infarction, in Wilkins RH (ed):

Cerebral Arterial Spasm. Baltimore: Williams \& Wilkins, 1980, pp 634-636

14. Selman WR, Spetzler RF, Roski RA, et al: Barbiturate coma in focal cerebral ischemia. J Neurosurg 56:685-690, 1982

15. Smith AL, Hoff JT, Nielsen SL, et al: Barbiturate protection in acute focal cerebral ischemia. Stroke 5:1-7, 1974

16. Traeger SM, Henning RJ, Dobkin W, et al: Hemodynamic effects of pentobarbital therapy for intracranial hypertension. Crit Care Med $697-701,1983$

17. Woodcock J, Ropper AH, Kennedy SK: High dose barbiturates in non-traumatic brain swelling: ICP reduction and effect on outcome. Stroke 13:785-787, 1982

Manuscript received August 24, 1998.

Accepted in final form September 24, 1998.

Address reprint requests to: Robert H. Rosenwasser, M.D., 834 Walnut Street, Suite 650, Philadelphia, Pennsylvania 19107. 